\title{
Is there a relationship between environmental factors and pityriasis rosea? Reply to Singh et al.
}

\author{
Francesco Drago ${ }^{1}$, Giulia Ciccarese ${ }^{1 凶}$, Aurora Parodi $^{1}$
}

Received: 3 July 2019 | Accepted: 26 September 2019

\section{To the Editor:}

We read with great interest the article by Singh et al. on the relationship between environmental factors and pityriasis rosea (PR), and between PR and dengue virus (DENV) infection (1), which allows us to make some considerations.

In their retrospective study, the authors found temporal clusters of PR in the autumn and winter months, although not in all the years analyzed and with a statistically significant but weak correlation.

A higher prevalence of PR in cold seasons has been claimed (2, 3), but controversial opinions remain (4), mostly connected with the occurrence of the disease in clusters (5). In our experience, PR develops evenly distributed throughout the year (6). These differences may be due to the geographical areas where the various studies are performed. Notably, Singh et al. (1) examined an environmental factor greatly overlooked in previous studies; namely, the main total rainfall. They found that heavy rainfall is linked to a decreased incidence of PR, suggesting that this happens because the vector mosquitoes of dengue fever decreased their breeding during the period of heavy rainfall. Furthermore, in their PR patients they found a positive correlation with the presence of NS1 antigen or antibody positivity against DENV in their serum. Therefore, they suggest that DENV may be one of the etiological factors for PR (1). In this regard, some remarks should be made. The authors state that the average time between dengue fever and the onset of PR was over 78 days, and they mentioned a pair of twins developing PR 5 weeks after dengue fever. However, the incubation period truly seems too long to ascribe DENV an etiological role in PR. In fact, exanthem in dengue fever (Herman's rash) has a maculopapular or macular confluent pattern developing over the face, thorax, and flexor surfaces, with islands of skin spar-

\section{References}

1. Singh M, Pawar M, Chuh A, Zawar V. Pityriasis rosea: elucidation of environmental factors in modulated autoaggressive etiology and dengue virus infection. Acta Dermatovenerol Alp Pannonica Adriat. 2019;28:15-20.

2. Chuang TY, Ilstrup DM, Perry HO, Kurland LT. Pityriasis rosea in Rochester, Minnesota: 1969 to 1978. J Am Acad Dermatol. 1982;7:80-9.

3. Harman M, Aytekin S, Akdeniz S, Inaloz HS. An epidemiological study of pityriasis rosea in the Eastern Anatolia. Eur J Epidemiol. 1998;14:495-7.

4. Chuh AA, Dofitas BL, Comisel GG, Reveiz L, Sharma V, Garner SE, et al. Interventions for pityriasis rosea. Cochrane Database Syst Rev. 2007;2:CDo05068.

5. Chuh AA, Molinari N, Sciallis G, Harman M, Akdeniz S, Nanda A. Temporal case clustering in pityriasis rosea: a regression analysis on 1379 patients in Minnesota, Kuwait, and Diyarbakir, Turkey. Arch Dermatol. 2005;141:767-71.

6. Drago F, Ciccarese G, Rebora A, Broccolo F, Parodi A. Pityriasis rosea: a comprehensive classification. Dermatology. 2016;232:431-7.

7. Drago F, Ciccarese G, Gasparini G, Cogorno L, Javor S, Toniolo A, et al. Contemporary infectious exanthems: an update. Future Microbiol. 2017;12:171-93.

8. Uno N, Ross TM. Dengue virus and the host innate immune response. Emerg Microbes Infect. 2018;7:167.

9. Aiba S, Tagami H. Immunohistologic studies in pityriasis rosea. Evidence for cellular immune reaction in the lesional epidermis. Arch Dermatol. 1985;121:761-5. ing that usually appear on the 3rd to 4th day of the fever and last 2 to 3 days. Fever typically abates with the cessation of viremia, usually 3 to 7 days after the onset of symptoms. A second maculopapular exanthem, which lasts 1 to 5 days, may occur within 1 to 2 days after the fall of the fever $(7,8)$. Such a long incubation time for PR makes a direct relationship unlikely for the DENV. Usually, the virus causes a cutaneous eruption, very different from the PR pattern after a short incubation period of a few days $(7,8)$. What is most likely is that DENV decreases the host's immunological response, permitting human herpesvirus 6 (HHV-6) and/or HHV-7 endogenous reactivation. In fact, the association of effective inhibition of type I interferon production and signaling in infected cells and effective modulation of infected cells such as monocytes, macrophages, B cells, and dendritic cells by DENV can decrease innate and adaptative immunity $(8,9)$. Regarding the possibility of an autoimmune mechanism in PR pathogenesis, suggested by the authors, this is unlikely. No specific autoantigens have ever been identified in PR, whereas immunohistological evidence of cellular immune response and an increased number of antigenpresenting cells in lesional skin have been well demonstrated $(9,10)$. Data from studies on mediators in the sera of PR patients showed high levels of interferon alpha and gamma, fractalkine, and interleukin 22, in agreement with a cell-mediated immune response against microbial pathogens (11-13). Indeed, several studies have identified HHV-6 and HHV-7 systemic activation in PR patients, HHV-6 and HHV-7 DNA and HHV-6 viral messenger RNA expression by in situ hybridization, and HHV-6 and HHV-7 antigens in PR skin lesions $(14,15)$ converging fully with a productive viral infection and emphasizing the role of both viruses in the pathogenesis of the disease. Finally, to date, everything suggests a cell-mediated immune response against HHV-6 and/or HHV-7.

10. Neoh CY, Tan AW, Mohamed K, Sun YJ, Tan SH. Characterization of the inflammatory cell infiltrate in herald patches and fully developed eruptions of pityriasis rosea. Clin Exp Dermatol. 2010;35:300-4.

11. Gangemi S, Cannavo SP, Guarneri F, Merendino RA, Sturniolo GC, Minciullo PL, et al. The $\mathrm{CX}_{3} \mathrm{C}$-chemokine fractalkine $\left(\mathrm{CX}_{3} \mathrm{CL}_{1}\right)$ is detectable in serum of patients affected by active pityriasis rosea. J Eur Acad Dermatol Venereol. 2006;20: 1366-7.

12. Gangemi S, Minciullo PL, Guarneri F, Cristani M, Arcoraci T, Spatari G, et al. Increased serum levels of interleukin-22 in patients affected by pityriasis rosea. J Eur Acad Dermatol Venereol. 2009;23:858-9.

13. Drago F, Ciccarese G, Broccolo F, Ghio M, Contini P, Thanasi H, et al. The role of cytokines, chemokines, and growth factors in the pathogenesis of pityriasis rosea. Mediators Inflamm. 2015;2015:438963.

14. Broccolo F, Drago F, Careddu AM, Foglieni C, Turbino L, Cocuzza CE, et al. Additional evidence that pityriasis rosea is associated with reactivation of human herpesvirus-6 and -7. J Invest Dermatol. 2005;124:1234-40.

15. Watanabe T, Kawamura T, Jacob SE, Aquilino EA, Orenstein JM, Black JB, et al. Pityriasis rosea is associated with systemic active infection with both human herpesvirus-7 and human herpesvirus-6. J Invest Dermatol. 2002;119:793-7. 